\title{
Recenzja
}

\section{Wojciech Sokolewicz, Prasa i Konstytucja, Wolters Kluwer business,Warszawa 201 1, ss. 276}

Recenzowana publikacja z jednej strony stanowi reasumpcję uregulowań dotyczących wolności prasy zawartych w Konstytucji z 1997 r. jako wartości ujętej na tle całej konstytucyjnej regulacji ustroju politycznego państwa. $\mathrm{Z}$ drugiej natomiast, ukazuje wolność prasy jako wolność obywatelską stwarzającą różnego rodzaju prawa podmiotowe, które zostały zaprezentowane przez autora w bardzo interesujący sposób. Główny nurt rozważań skupia się nad kwestią w jaki sposób w praktyce działania władz państwowych sprawdza się owe konstytucyjne ujęcie prasy jako jednej z naczelnych zasad prawnych ustroju politycznego państwa.

Warto podkreślić, iż jest to pierwsza tego typu publikacja w której kompleksowo zostały omówione praktyczne kwestie wolności prasy (mediów) nie tylko z perspektywy prawa konstytucyjnego, ale również z punktu widzenia prawa cywilnego, administracyjnego i karnego. Dlatego też należy wyrazić uznanie dla autora, iż w tak przejrzysty i syntetyczny sposób ukazał różne problemy (teoretyczne i praktyczne) funkcjonowania wolności prasy na tle obowiązującego porządku prawnego.

Należy również zauważyć, iż podjęta przez autora tematyka jest istotna przynajmniej z dwóch względów. Po pierwsze wolność prasy ma podstawowe znaczenie dla funkcjonowania demokratycznego państwa prawnego. W literaturze przedmiotu wskazuje się, że przestrzeganie i rozwój wyszczególnionych w Konstytucji z 1997 r. wolności i praw jest z jednej strony miernikiem, a $\mathrm{z}$ drugiej fundamentem demokracji danego państwa. Po drugie, wolność prasy utożsamiana jest ze środkiem dla realizacji m. in. dwóch pierwszych artykułów Konstytucji, które stanowią fundament ustrojowy państwa polskiego. Z tego też względu autor słusznie dostrzega logiczny związek i „przenikanie się" konstrukcji demokratycznego państwa prawnego, z zasadą wolności prasy.

Recenzowana publikacja podzielona jest na VI rozdziałów. Pierwszy rozdział nosi tytuł „Prasa a system władz politycznych”. Rozdział ten jest naj- 
lepszym punktem wyjścia dla dalszych, bardziej szczegółowych rozważań zawartych w rozdziale II traktującym o wolności prasy jako konstytucyjnej zasadzie ustroju państwa. Początek rozdziału II ukazuje genezę historyczną oraz odniesienia porównawcze konstytucyjnego ujęcia wolności prasy w Polsce. We wstępie pracy autor wprawdzie stwierdza, że „perspektywę historyczną przyjmuje tylko sporadycznie i tylko wtedy, gdy służy ona lepszemu zrozumieniu problemów występujących na tle obecnie obowiązujących rozwiązań i konstrukcji prawnych [...]", jednakże historyczne ujęte tego podrozdziale budzi pewien niedosyt. Nie ma to jednak istotnego wpływu na zawarte w nim rozważania. Na szczególną uwagę zasługują rozważania zawarte w podrozdziale 9 zatytułowanym „Wolność elektronicznych środków społecznego przekazu jako kwalifikowana forma wolności prasy (mediów) w ogólności” w którym autor słusznie wskazuje, iż „zabezpieczenie wolności prasy, a już w szczególności mediów elektronicznych, wymaga wzmożonej aktywności państwa - regulacyjnej, reglamentacyjnej i prowadzonej w każdej innej dostępnej władzom formie".

Rozdział III traktuje o gwarancjach wolności prasy oraz wskazuje na skomplikowane relacje zachodzące pomiędzy tytułową wolnością prasy oraz wolnościami i prawami pokrewnymi jak np. wolność wypowiedzi. Ponadto, autor opisuje w nim Krajową Radę Radiofonii i Telewizji jako strażnika wolności słowa w mediach elektronicznych. W dalszej części, analizie poddana została cenzura prewencyjna odnosząca się do wszelkich środków społecznego przekazu oraz quasi-cenzura, polegająca na cenzurze następczej materiałów prasowych. Istotna część niniejszego rozdziału została poświęcona ochronie tajemnicy dziennikarskiej jako jednej z gwarancji wolności mediów. W świetle zawartych w tym podrozdziale wniosków, należy przychylić się do zaprezentowanego przez autora stanowiska, o restrykcyjności ustawodawstwa polskiego, które przyznaje pierwszeństwo wolności prasy i jej gwarancji wobec potrzeb efektywnego wymiaru sprawiedliwości. Słusznie wskazuje W. Sokolewicz, iż ochrona tajemnicy dziennikarskiej, uznawana za logiczne następstwo wolności wypowiedzi, pozostaje jedną z najważniejszych gwarancji wolności prasy i swobody krytyki prasowej.

W rozdziale IV, zatytułowanym „Uwarunkowania i ograniczenia wolności prasy”, autor wskazuje, iż wolność prasy, podobnie jak wolność słowa (wypowiedzi) nie ma charakteru absolutnego i po spełnieniu ściśle określonych warunków może zostać ograniczona. Zgodzić się więc należy z autorem, iż 
przesłanki ograniczenia realizacji konstytucyjnych wolności i praw należy interpretować zawężająco, zgodnie z tym, iż wolność słowa (wypowiedzi, prasy) jest zasadą, a ograniczenia mogą mieć miejsce jedynie wyjątkowo. Rozwinięciem tych rozważań jest podrozdział 2, w którym wskazane zostały konstytucyjne przesłanki ograniczenia wolności prasy poprzez koncesjonowanie mediów elektronicznych. W dalszej części tego rozdziału poruszony został niezwykle istotny problem kolizji misji środków społecznego przekazu $\mathrm{z}$ innymi chronionymi prawnie wartościami jak np. ujawnienie informacji niejawnych lub prawo do prywatności osób prywatnych i osób publicznych. Jak słusznie wskazano, przedmiotem tej ochrony są w szczególności fakty dotyczące poszczególnych osób lub dotyczące ich przeżycia, które generalnie nie powinny ujrzeć światła dziennego i być rozstrzygane na forum publicznym. Tym samym, prawo do prywatności zachowuje nadrzędność w stosunku do innych praw podmiotowych. Jednakże $\mathrm{z}$ różną intensywnością możemy mówić o ochronie prywatności według kryterium przedmiotowego w stosunku do osób publicznych, gdzie granice są szerzej otwarte (np. w stosunku do polityków), niż osób prywatnych. Dalszą część rozdziału autor poświęcił na zagadnienie związane z krytyką osób pełniących funkcje publiczne, osób publicznych i funkcjonariuszy publicznych, podkreślając, że swoboda debaty na tematy polityczne osłabia (ale nie znosi) ochronę dobrego imienia tych osób. $\mathrm{Z}$ drugiej strony, prawo chroni krytykę osób pełniących funkcje publiczne, ale tylko wyłącznie wtedy gdy jest ona: rzetelna; podjęta została w interesie publicznym; jej przedmiotem jest działalność związana $\mathrm{z}$ wypełnianiem funkcji publicznych; nie przybiera form poniżających krytykowanego oraz oparta jest na faktach. Dlatego też należy przychylić się do stwierdzenia, że określenie granic dopuszczalności krytyki osób pełniących funkcje publiczne jest skomplikowane, a oceny krytyki tych osób dokonywać należy in concreto, uwzględniając całokształt okoliczności faktycznych i prawnych analizowanego przypadku.

Tematyką przedostatniego rozdziału jest przedstawienie odpowiedzialności dziennikarzy za nadużycie wolności prasy na gruncie nie tylko prawa karnego, ale również prawa pracy i prawa cywilnego. Jak wskazuje W Sokolewicz, odpowiedzialność cywilna i karna nie wykluczają się wzajemnie, lecz mogą być dochodzone równolegle. W dalszej części rozdziału autor w sposób przejrzysty i ciekawy opisuje przesłanki umożliwiające pociągnięcie dziennikarzy do odpowiedzialności, zarówno na gruncie prawa karnego (zniesławie- 
nie lub znieważenie), jak i prawa cywilnego (naruszenie dobra osobistego). W związku z tym w dalszej części niniejszego rozdziału zostały omówione nie tylko przesłanki warunkujące odpowiedzialność dziennikarzy, ale również uchylające i ograniczające bezprawność treści i formy jego publikacji. Istotne rozważania znalazły się w podrozdziale dotyczącym form reakcji na zamieszczony materiał prasowy. Wskazują one, iż nie zawsze opublikowane sprostowanie lub zamieszczone przeproszenie zdolne jest naprawić wyrządzoną krzywdę. Zdaniem autora brak w prawie definicji sprostowania oraz określenie jedynie okoliczności uzasadniających żądanie jego publikacji jest nieprecyzyjne i znacznie ogranicza efektywność tego środka. Nie przekreśla to jednak samej natury uregulowań odnoszących się do sprostowania, odpowiedzi lub żądania przeprosin wynikających z Prawa prasowego.

Ostatni, VI rozdział publikacji, omawia przesłanki ograniczenia wolności prasy na tle ograniczeń wolności i praw wynikających z art. 31 ust. 3 Konstytucji z 1997 r. Autor ukazuje wzajemne relacje środków ograniczenia wolności prasy (mediów) do ogólnych przesłanek ograniczenia wolności i praw człowieka i obywatela. Zdaniem W. Sokolewicza, należy wypowiedzieć się za adekwatnością przesłanek materialnych ograniczenia realizacji wolności i praw konstytucyjnych z art. 31 ust. 3 Konstytucji do ograniczenia wolności prasy. W związku z powyższym dalsza część publikacji stanowi praktyczne omówienie przesłanek zawartych w art. 31 ust. 3 Konstytucji z odniesieniem ich do wolności prasy (mediów).

W zakończeniu recenzowanej publikacji, autor słusznie wskazuje, na złożoność zasady wolności prasy występującą na gruncie Konstytucji z 1997 r. Zdaniem autora, konstytucyjna zasada wolności prasy realizowana m. in. poprzez przepisy Prawa prasowego jest regulacją anachroniczną i jako zbędna, może zostać zastąpiona nie tylko przepisami prawa karnego, administracyjnego czy też cywilnego, ale również środowiskowymi samoregulacjami. Nadto, wolność prasy jest jedną z naczelnych zasad Konstytucji. Dlatego też z pozostałymi zasadami (przepisami) musi pozostawać w niezbędnych relacjach. $\mathrm{Z}$ jednej strony relacje te pozostają w pełnej harmonii i wzajemnej komplementarności (np. z prawem do informacji publicznej), z drugiej krzyżują się, powodując różnego rodzaju kolizje (np. obowiązek poszanowania i ochrony godności człowieka). Dlatego też są one miejscami trudne do rozstrzygnięcia i nastręczają wiele praktycznych problemów (np. zderzenie wolności prasy z ochroną dóbr osobistych). Mając na uwadze powyższe, autor stwierdza, iż 
każda tego typu sprawa wymaga osobnego podejścia organu rozstrzygającego i wnikliwego wyważenia racji.

Również należy przychylić się do konkluzji autora, wskazującej na konieczności ochrony tajemnicy dziennikarskiej stanowiącej jedną z gwarancji wolności prasy i urzeczywistniającej poziom rozwoju demokracji danego państwa. Wzmocnienie to, winno nastąpić poprzez zmianę przepisów uniemożliwiających występowanie dziennikarzy w charakterze świadka w sprawach w których może nastąpić ujawnienie tajemnicy dziennikarskiej. Także, należy wprowadzić bezwzględną ochronę danych osobowych dziennikarzy zastrzegających sobie anonimowość.

Po lekturze recenzowanej publikacji, z całą stanowczością należy wskazać na jej wartość naukową i poznawczą oraz bardzo interesujące i praktyczne ujęcie istoty problemów wolności prasy na tle uregulowań zawartych w Konstytucji z 1997 r. Polska literatura dotycząca ochrony wolności prasy (mediów) - coraz bogatsza - nadal wymaga wielu uzupełnień i w tym zakresie niniejsza publikacja nie tylko wzbogaca ale i porządkuje dorobek doktryny $\mathrm{w}$ tym przedmiocie.

Łukasz Kojara

(Uniwersytet Kardynała Stefana Wyszyńskiego) 